\title{
Salgın Sürecinde Romanların Gündelik Hayatındaki Dönüşümün Medyadaki Görünümü
}

\author{
Ozan Uş̧uk ${ }^{1}$ \\ ORCID: 0000-0002-4062-8404
}

\author{
Ece Güleç² \\ ORCID: 0000-0002-2725-863X
}

\section{Öz}

Bu çalışma, koronavirüs pandemisinin Roman toplulukların gündelik hayatlarında meydana getirdiği dönüşümü, Romanların yaşam alanları, ekonomik etkinliklerini sürdürdüğ̈̈ kamusal alanlar ve yerel yönetimler ile ilişkileri çerçevesinde haber metinleri üzerinden incelemektedir. Yerel ve merkezi yönetim kademelerinde yer alan aktörlerin kent mekânına yönelik politikalarını gerekçelendirme aracı olarak kültür-merkezci söylem setini medya üzerinden dolaşıma sokmalarna dair irdeleme, hem Roman topluluklar ile siyasal aktörler arasinda cereyan eden süreçleri anlamlandırma, hem de gizlenmekte olan eşitsizlikleri serimleme imkânı tanımaktadır. Eleştirel söylem analizi yöntemi benimsenen çalışmada, öncelikle pandemi sürecinde derinleşen yoksulluğa dair genel bir çerçeve çizilmekte, ardından Romanları konu alan haberler incelenmektedir. Bu çerçevede ilk olarak Romanların yoksulluk deneyimlerinin medya aracılı̆̆ıyla nasıl dolaşıma sokulduğu irdelenmektedir. İkinci olarak gündelik hayatın dönüşümüne eşlik eden ırkçı söylemlerdeki yükselişi ve bu söylemlerin sınıfsal eşitsizlikleri nasıl gizlediği yorumlanmıştır. Üçüncü olarak yerel ve merkezi yönetimlerin Romanların yaşam alanlarında gerçekleştirdiği tahribatlar ve bu sürecin neoliberal kent politikalarn ile ilişkisi değerlendirilmiştir. Son olarak siyasal aktörlerin Romanların yaşam mücadelesini kendi gündemlerini oluşturmak adına araçsallaştırmaları çerçevesinde kurgulanan metinlerin eleştirel bir okuması yapılmıştır.

Anahtar Kelimeler: Romanlar, kent politikaları, gündelik hayat, COVID-19 salgını, eleştirel söylem analizi.

\footnotetext{
${ }^{1}$ Öğr. Gör. Dr., İzmir Yüksek Teknoloji Enstitüsü, E-mail: ozanustuk@iyte.edu.tr

${ }^{2}$ Arş. Gör., İzmir Yüksek Teknoloji Enstitüsü, E-mail: ecegulec@iyte.edu.tr

idealkent @ Kent Araştırmaları Dergisi (Journal of Urban Studies) 


\title{
Media Coverage of the Transformation of Everyday Life of Roma Communities during Covid-19 Pandemic
}

\author{
Ozan Uştuk ${ }^{3}$ \\ ORCID: 0000-0002-4062-8404
}

\author{
Ece Güleç4 \\ ORCID: 0000-0002-2725-863X
}

\begin{abstract}
This study examines the transformation of the everyday life of Roma communities during the Covid-19 pandemic through media coverages by focusing on their living spaces, public spaces where they continue their economic activities and build their relations with local governments. Examining the culture-centered discourses revolving around the central and local governmental interventions towards the Roma living spaces amidst the pandemic and the relevant media exposure is herein essential so as to understand the power dynamics between Romani communities and political actors.

Employing a critical discourse analysis method, we have initially drawn a general framework about extreme poverty, and subsequently surveying the media coverage on the Roma people. Against this backdrop, we firstly looked at the media depiction of the Roma's experiences regarding extreme poverty. Secondly, we interpreted the rise of racist discourses accompanying the transformation of everyday life and how are these discourses conceal inequalities regarding class inequalities. Thirdly, we investigated the damage caused by local authorities to the living spaces of Roma and the interrelation of these damages to neoliberal urban policies. Finally, we engaged a critical reading of the news, in which we noticed the struggle of Roma people is instrumentalized by political actors into their agendas.
\end{abstract}

Keywords: Roma, urban policies, everyday life, COVID-19 pandemic, media, critical discourse analysis.

\footnotetext{
${ }^{3}$ Instructor Dr., Izmir Institute of Technology, E-mail: ozanustuk@iyte.edu.tr

${ }^{4}$ R. A., Izmir Institute of Technology, E-mail: ecegulec@iyte.edu.tr

idealkent @ Kent Araştırmaları Dergisi (Journal of Urban Studies) 


\section{Giriş}

2019 yılının Aralık ayında, Çin'in Wuhan şehrinde ortaya çıkan COVID-19 pandemisi, takip eden üç ay içerisinde Türkiye'nin sosyal ve akademik gündemine oturmuştur. Bu süreci takiben, pandeminin sosyal, ekonomik ve politik etkileri üzerine çeşitli disiplinlerden çok sayıda araştırma yürütülmüştür. Pandeminin etkisinin ve hükümetlerin önlem programlarını özellikle dezavantajlı topluluklar üzerinde ağır etkiler yaratması nedeniyle salgının sınıfsal etkileri dikkat çekmeye başlamış, yayınlanan haberler ve raporlar sayesinde pandeminin sosyal eşitsizlikler ile ilişkisi belirginleşmiştir. Pandemiden etkilenen dezavantajlı gruplar arasında en dikkat çeken gruplardan biri Avrupa'da yaşayan Roman topluluklar olmuştur. 7 Nisan 2020'de, Avrupa Birliği Temel Haklar Ajansı, Avrupa Güvenlik ve İşbirliği Teşkilatı Demokratik Kurumlar ve İnsan Hakları Ofisi ve Avrupa Konseyi, Roman toplulukların pandemi koşullarında anaakım gruplara göre orantısız bir şekilde risk altında olduklarına dair ilk açıklamalarda bulunmuştur (Matache ve Bhabha, 2020, s. 379). Bu açıklamaları takiben üretilen yayınlarda üç ortak temanın sıkça tekrarlandığı görülmüştür. Bu temalar, Romanlara yönelik nefret söylemlerindeki artış, Roman toplulukların ırkçı grupların hedefi haline gelmeleri ve Romanların pandeminin yayılmasından sorumlu tutularak etnik günah keçisi ilan edilmeleridir (Berta, 2020; Costache, 2020; Gay y Blasco ve Rodriguez Camacho, 2020; Matache ve Bhabha 2020; Reuters Staff, 2020).

Türkiye Romanlarının pandemi şartlarında olumsuz yönde dönüşmekte olan gündelik hayatlarının anaakım medya kuruluşlarına bağlı haber kaynaklarında yeterince yer bulamadığı ya da haber içeriklerinin ait oldukları mülkiyet/sahiplik ilişkilerinin ideolojik doğasından ötürü yanlış ve sorunlu temsiller ürettiği görülmüştür. Medya sektöründeki tekelleşme ve medya patronlarının iktidar ve hâkim ideolojiyle kurdukları ilişki nedeniyle madun kesimlerin yaşadıkları hak ihlalleri gerektiği biçim ve ölçüde temsil edilmemektedir (Tokdoğan, 2013, s. 14). Bu şartlar altında Sivil Toplum Kuruluşlarının (STK) gündemi belirleme çabaları da, gerek seslerinin kısık çıması, gerekse de egemen dile karşı alternatif üretememeleri sebebiyle benzer temsilleri yeniden üretmeleri ile sonuçlanmaktadır. Bu durum, hâlihazırda kendi anlatılarını üretmekte başarı gösteremeyen Roman toplulukların (Hancock, 2011) iyice sessizleştirilmesinin yanı sıra Roman mahalleleri başta olmak üzere kentsel kamusal alanlarda yaşadıkları hak ihlallerinin de gizlenmesine yol açmaktadır. Salgın sürecinde Romanların yaşam alanlarında meydana gelen tahribatın kent politikaları ile 
ilişkisi ve bu ilişkinin medyaya yansıma biçimlerinin incelenmesi, kültürel kimliği dolayımlayan güç ilişkilerini anlamak için elzemdir. Merrifield'a göre (2014, s. 30) neoliberal kentlerde sakinlerin ihtiyaçlarından ziyade piyasanın ihtiyaçları dikkate alınmakta, gündelik hayatı ve kentlerdeki kolektif birikimi hiçe sayan bir yıkım gerçekleşmektedir. Yerel ve merkezi yönetim kademelerinde yer alan aktörlerin kent mekânına yönelik politikalarını gerekçelendirme aracı olarak kültür-merkezci söylem setini medya üzerinden dolaşıma sokmalarına dair irdeleme, hem Roman topluluklar ile siyasal aktörler arasında cereyan eden süreçleri anlamlandırma, hem de gizlenmekte olan eşitsizlikleri serimleme imkânı tanımaktadır.

$\mathrm{Bu}$ tespitlerden hareketle, çalışmada öncelikle derinleşen yoksulluğa dair genel bir çerçeve çizilmiş, ardından merkezi ve yerel yönetimlerin pandemi sürecinde Romanların yaşam alanlarına müdahaleleri başta olmak üzere Romanların medyada nasıl yer buldukları eleştirel bir irdelemeye tabi tutulmuştur.

\section{Pandemi ve Derinleșen Kent Yoksulluğu}

Oscar Lewis'in $(1968 ; 1969)$ yoksulluk kültürü tezini ortaya attığı 1960'ların sonlarından günümüze, kentin dezavantajlı ve etnik gruplar tarafından mesken edinilen gecekondu bölgeleri ve informel yerleşkelerdeki yaşam koşullarının zorluğu üzerine oldukça yüklü bir akademik literatür gelişmiştir. Ancak pandemi ile yoksul meskenlerde hayatta kalma mücadelesi veren toplulukların gündelik ritim, rutin ve ritüellerinin derinden sarsıldığına şahit olunmaktadır. Devlet eliyle yapılan düzenleme ve kısıtlamaların, pandemi ve beraberinde getirmiş olduğu sorunlara ivedilikle cevap üretmekte yetersiz kaldığı ortaya çıkmıştır. Kent yoksullarının yaşadığı mekânlarda, temiz su, tuvalet, kanalizasyon, drenaj, atık yönetim sistemleri, konut ve diğer temel ihtiyaçların karşılanamaması (Corburn ve diğerleri, 2020, s. 349), pandeminin dezavantajlı topluluklar açısından daha ağır şartlarda geçmesine neden olmaktadır. Gecekondu bölgelerinde nüfus yoğunluğunun yüksek olması ve yoksul kesimler arasında yaygın olarak tercih edilen toplu taşıma kullanımının çeşitli kesimlerden insanların karşılaşmalarını arttırması fiziksel mesafenin korunmasını zorlaştırarak bulaşının hızlanmasına sebep olmaktadır. Ayrıca yoksul yerleşkelerdeki su ve sanitasyon problemlerinin de SARS-CoV-2 ve benzeri virüslerin yayılmasına sebep olduğu ve ekonomik nedenlerle sağlık hizmetlerine erişimi sınırlı kesimlerin ciddi risk altında olduğu bilinmektedir (Baker, Cira ve Lall, 2020, s. 9-10).

Bu bağlamda etnik kimlik, sağlık hizmetlerine erişimi etkileyen bir faktör olarak karşımıza çıkmaktadır (Azar ve diğerleri, 2020; Wiemers ve diğerleri, 
2020). Salgının etkilerinin artmasıyla birlikte etnik azınlıkların ve dezavantajlı grupların, sağlık hizmetlerinden faydalanmaları giderek zorlaşmakta buna bağlı olarak ölüm oranlarının yükselişi rakamlara yansımaktadır (Azar ve diğerleri, 2020). Amerika Birleşik Devletleri'nin Hastalık Kontrol ve Önleme Merkezinin (Centers for Disease Control and Prevention [CDC], 2020) 25 Haziran 2020 tarihli raporuna göre, koronavirüsün etnik gruplar arasındaki dağılımı çerçevesinde tespit edilen farklılıklar, yaşam, çalışma, sağlık ve sosyal koşullardaki eşitsizliklerden kaynaklanmaktadır. Irk temelli mekânsal ayrımcllıktan muzdarip mahallelerdeki yoğun nüfus oranları, fiziksel mesafenin korunmasına imkân tanımadığı gibi, geniş ailelerin bir arada yaşamak zorunda kaldıkları konutlarda (CDC, 2020), yaşlı ve hasta bireylerin izole edilmesi gibi tedbirlerin uygulanmasını imkânsız hale getirmektedir (Tampe, 2020, s. 1). Haliyle gelişmekte olan, kayıt dişı ekonomilere yaslanan ve kriz yaşamakta olan ülkeler pandemi karşısında büyük kırılganlığa sahipken bu ülkelerdeki kadınlar, engelliler, mülteciler ve yerinden edilen kesimler en büyük darbeyi almaktadır (United Nations Development Programme [UNDP], 2020). Hâlihazırda dezavantajlı konumda olan, temel ihtiyaçlara ulaşmakta bile güçlük çeken grupların yaşam koşulları daha yıkıcı hale gelmiştir (Tampe, 2020, s.1). Bu bağlamda pandeminin toplumsal yaşamda kanıksanmış eşitsizlikleri açığa çıkaran bir işlevi olduğu söylenebilir.

Mekânsal dezavantajların yanı sıra, pandeminin kent yoksulları üzerindeki en büyük etkileri ekonomik alanda görünürlük kazanmaktadır. Uluslararası Çalışma Örgütü'nün verilerine göre, sokağa çıkma yasakları ve hükümetlerin karantina tedbirleri sebebiyle, işyerlerinin yaklaşık yüzde 70'i kapanmıştır. Kayıt dışı alanda işten çıartmaların artacağını, çalışan kayıt dışı emekçilerin ise kazançlarının azalacağını ve küresel çapta nispi yoksulluğun artacağını belirten Uluslararası Çalışma Örgütü'ne göre "sınırlama önlemleri kaldırıldıktan sonra bile, hayatta kalan işletmeler ve kendi hesabına çalışanlar zorluklarla karşılaşmaya devam edecektir" (International Labour Organization [ILO], 29 April 2020). Dünyadaki tüm yeni istihdam firsatlarının yaklaşık yüzde 85'i kayıt dışı ekonomide gerçekleşmektedir (UN-Habitat, 2015; UN-Habitat, 2011). Ülkelerdeki ekonomik faaliyetler dramatik bir şekilde yavaşlayacağından, kentsel yoksulların gelir kaybının, sosyal koruma, tasarruf veya güvenlik ağlarının eksikliği göz önüne alındığında hane halkı üzerinde olumsuz etkileri olacağı öngörülmektir (Baker ve diğerleri, 2020, s. 10-11). Türkiye'de yaşamakta olan Roman toplulukları da genelde kayıt dışı ekonomik faaliyetler çerçevesinde yaşamlarını idame ettirdikleri için her geçen gün yoksulluğun daha derin fazlarına doğru itilmektedir. 


\section{Yöntem}

Bu çalışmada, yoksulluk halleri pandemi ile daha derin fazlara itilen Roman topluluklarının kent ile kurdukları dinamik ilişkinin haber metinlerine yansıma biçimleri, eleştirel söylem analizi yöntemi ile incelenmiştir. 2001 ekonomik krizinin ardından Türkiye'de medya sahiplikleri "hükümet yanlısı" ve "karşıtı" biçiminde siyasi amaçlara hizmet edecek şekilde yeniden yapıland1rılmıştır (Kurban ve Sözeri, 2012, s. 11). Öte yandan etnik gruplar söz konusu olduğunda, "medya pratiklerinin muhalefet ve eleştiri içerdiği zamanlarda bile temel normlara, değerlere ve iktidar düzenlemelerine açık bir meydan okuma gerçekleştirebildiği nadiren görülür" (Van Dijk, 2005, s. 351). Depeli'ye göre (2013, s. 46) "Türkiye medyası, egemen söylemsel ideoloji karşısındaki güçsüz grupları, ayrımcı, sosyal ve ahlaki açıdan olumsuz kodlamaların sayısız örneğini vermiş ve bu grupları bir özne olarak temsil etmek yerine kendi ideolojik kodlarının içerisinde keyfi olarak kurguladığı anlatıların nesnesi haline getirmiştir". Roman toplulukları da bu nesneleştirmeden muaf değildir. Romanların temsillerini üreten ve dolaşıma sokan haberlerin, neyi anlattığ ve sermayenin işbirliği çerçevesinde nasıl belirlendiğini çözümlemek önem arz etmektedir. Nihayetinde, "kültürel üretimin ekonomi politiği, sahne gerisindeki geniş iktidar ve mülkiyet modellerinin medya ürünlerini üretmenin mahiyeti ve işleyişi üzerindeki somut sonuçlarıyla ilgilenir" (Golding ve Murdock, 1997, s. 67). Bu ilgiden hareket eden çalışma, Romanların pandemi şartlarında kötüleşen kent içi yoksulluk deneyimlerinin medyadaki yansıma biçimlerine odaklanmaktadır. Bu doğrultuda, Türkiye'de COVID-19 virüsünün tespit edildiği 11 Mart 2020 ve 24 Aralık 2020 tarihi arasında yayınlanmış Romanları konu alan ve içinde "Roman" kelimesi geçen 67 haber metnine erişilmiş ve bu metinlerin tamamı incelenmiştir.

Bu kapsamda ilk olarak Romanların yoksulluk deneyimlerinin medya aracıllğıyla nasıl dolaşıma sokulduğu irdelenmektedir. İkinci olarak gündelik hayatın dönüşümüne eşlik eden ırkçı söylemlerdeki yükseliş ve bu söylemlerin sınıfsal eşitsizlikleri nasıl gizlediği yorumlanmıştır. Üçüncü olarak yerel ve merkezi yönetimlerin Romanların yaşam alanlarında gerçekleştirdikleri tahribatlar ve bu sürecin neoliberal kent politikaları ile ilişkisi değerlendirilmiştir. Son olarak siyasal aktörlerin Romanların yaşam mücadelesini kendi gündemlerini oluşturmak adına araçsallaştırmaları çerçevesinde kurgulanan metinlerin eleştirel bir okuması yapılmıştır. 
Söylem analizi yöntemi ile Romanlara dair gündelik hayattaki gelişmelerin medyadaki temsil biçimlerinin haberler üzerinden incelenmesi, iktidar odaklarının karar ve edimlerinin gündelik hayata sirayet etme biçimlerine ilişkin çıkarımda bulunulması ve medya, yerel yönetimler ve kent arasındaki karmaşık güç dinamiklerinin sergilenmesi açısından faydalıdır.

\section{Haber Metinlerinde Roman Temsilleri}

Romanların pandemi döneminde haber metinlerine yansıma biçimleri incelendiğinde iki karşıt söylemsel yönelim belirginleşmektedir. Bunlardan ilki pandemi ile birlikte derinleşen yoksulluğun Roman mahallelerindeki görünümüne odaklanan metinler, ikincisi ise içerikte yoksulluğa merkezi bir önem atfetmeyen, Romanların kültürel yaşam biçimlerini merkeze alarak "ötekiliği metalaştıran" (hooks, 2015, s. 44) ve yapısal eşitsizlikleri gizleyen metinlerdir.

Pandemiyle birlikte Roman toplulukların karşılaştıkları zorlukları yansıtan haberlerin çoğunda, Romanların "virüsten çok açlıkla mücadele ettiği" ve "her an afetteymiş gibi yaşayarak kendilerine hayatta kalma stratejisi" geliştirmeleri gerektiği yer bulmuştur ("48 Örgütten Ortak Açılama", 2020). Çeşitli haberlerde Romanların "açlık sınırının altında" olduğu (Torun, 2020) farklı biçimlerde vurgulanmıştır. Pandemi şartlarında Romanların "çöplerden ekmek toplayarak" (Kaya, 2020) veya "sokaklardan ebegümeci toplayarak" gıda ihtiyaçlarını karşılamak zorunda kaldıklarına yönelik görsel imgeler çağrıştıran metinlerin yanı sıra (Tok, 2020), "hayal edilemeyecek kadar kötü bir durum" ile karşı karşıya oldukları ve virüsten olmasa bile "açlık ve bakımsızlık" (Tok, 2020) nedeniyle meydana gelecek "toplu ölümlerden korktukları" (Kaya, 2020) ifadelerinin yer aldığı haberler ön plana çıkmaktadır. Yoksulluğun pandeminin etkisi ile derinleştiği bu dönemde, "bağışıklık sistemini güçlendirecek şekilde beslenemeyen Romanların salgından etkilenmelerinin kaçınılmaz" olduğu ve "çoğu mahallenin fatura borçlarından dolayı susuz veya elektriksiz kaldığı" belirtilmiştir ("Kağıt ve Hurda Toplayan Romanlar", 2020). Bu bağlamda derin yoksulluğu konu alan gazetelerin ele aldığı meseleler, marjinal toplulukların pandemi ile daha büyük risk altına girdiğine yönelik akademik çalışmaların öngörüleri (Cole ve diğerleri, 2020, s. 1) ile paralellik göstermektedir.

Roman toplulukların toplumsal ve mekânsal sorunlarının yanı sıra, Roman kadınların yaşadığı zorlukların pandemide arttığı görülmektedir. Diana Pearce (1978) tarafından ortaya atılan yoksulluğun kadınlaşması olgusu, "hane tüketim ve gelir istatistiklerine yansımayan" (Fukuda-Parr, 1999, s. 
101) ancak kadınların erkeklere göre daha düşük kazanç elde etmeleri (McLanahan ve Kelly, 1999, s. 127) başta olmak üzere birçok sebepten ötürü yoksulluğu erkeklere göre daha derin deneyimlediklerine (Çamur Duyan, 2010, s. 20) işaret etmek için kullanılagelmiştir. Haberlerden de izlenebileceği üzere çiçekçilik ve kâğıtçlık yaparak geçimini sağlayan genç Roman kadınlar, pandemide geçimini sağlayamaz hale gelmiştir (Sivrikaya, 2020). Buna bağlı olarak eğitim alt yapısına ulaşamayan kız çocuklarının da bakım zorluğu yüzünden evlendirilme oranının arttığ1 görülmüştür ve bu durum "evden bir boğaz kesildi" (Sivrikaya, 2020) ifadesi ile haberlerde yer bulmuştur. Yoksulluğun kadınlaşmasına yaptığı vurgu ile Gazete Duvar, "Roman Kadınlar Anlatıyor: Çözülmesi gereken çok problem var" (Sivrikaya, 2020) ve "Kapı kapı dolaşarak Roman kadınlara İstanbul Sözleşmesi'ni anlatıyor" (Nida, 2020a) başlıklarını atmıştır. Ayrıca pandemi sürecinde yaşanan kapanmanın hane içi şiddeti arttırdığına yönelik metinler (Nida, 2020a) Roman kadınların yaşadığ zorlukları görünür kılmaktadır.

Türkiye'de merkez medya son 15 yıllık süreçte "doğrudan iktidarın müdahalesi ile hızlı, siyasi, ekonomik ve yapısal değişimlere ve el değiştirmelere" maruz kalmıştır (Depeli, 2013, s. 47). Bu değişimlerin marjinal grupların medyada yer alma oranları ve tarzları üzerinde büyük etkileri olmuştur. Romanların, pandemide deneyimledikleri zorlukların, derin yoksulluğun ve maruz kaldıkları ayrımcılığın bahsinin geçmediği haberler tüm haberlerin yaklaşık yüzde 25'ini oluşturmaktadır. Ancak buradan Romanların Türkiye medyasındaki temsilinin hak temelli bir gazetecilik çerçevesinde ve geniş çaplı temsil edildiğini çıkarsamak doğru olmayacaktır. Aksine merkez medya, bu grupların görünürlügünü azaltarak, yapısal eşitsizliklere örnek teşkil edecek hallerini gizlemektedir. Medyanın sınıfsal gerçeklikleri örten bu ideolojik konumlanması, Roman topluluklarının pandemi sürecinde deneyimledikleri olağanüstü zorlukları gizleyen ve kültürel yaşam biçimlerini egzotize ederek metalaştıran bir eğilim ihtiva etmektedir. Örneğin "İstanbul'da Roman Havası" ("İstanbul' da Roman Havası", 2020), "Romanlar koronavirüs nedeniyle günlerini kutlayamadı" ("Romanlar 49 Yıl Sonra", 2020) gibi başlıklar "eğlence kaynağı" olarak görülmek istenen bir Roman temsili üretmeye hizmet etmektedir. Bu metinlerde Romanlar, kendilerine özgü müzikler ile kent bağlamında eğlenceli atmosfer ile imgeleştirilerek görünür kılınmaktadır. Sınıfsal eşitsizliklerden en büyük yarayı alan Romanların istihdam problemleri ayan beyan ortada olmakla birlikte, metinlerdeki söylemsel manevralar sanki bu problemlere çözüm üretilmiş izlenimi yaratmaktadır. Örneğin, 
"Meclis başkanı Romanlar Günü'nü kutladı" (Akan, 2020), "Roman müzisyenler maharetlerini sergiledi" (Demirci, 2020), "Pandemi döneminde Roman havası" (Erbalaban Yılmaz, 2020), "Ramazan davulcuları mesaiye başladı" (Yılmaz, 2020), "Roman kadınların ellerinde şekillenen enstrümanlar yurt d1şına pazarlanacak" (Avc1, 2020) ve "Lüleburgaz'da 100 davulcu ramazanda görev yapacak" ("Lüleburgaz'da 100 Davulcu", 2020) ifadeleri pandemi şartlarında Romanlara istihdam olanağı sağlandığı izlenimi üretmeye çalışmaktadır. Bu minvalde bazı yerel yönetimlerin etkinliklerine dair haberler de gündemi meşgul etmiştir. Örneğin, İstanbul Büyükşehir Belediyesi'nin Kültür Daire Başkanlığ 1 ile iş birliği yaparak çalışamayan Roman sanatçlara destek olmak amaciyla 2 günlük bir program ile Roman müzisyenlerin müzik ve dans performansı sergilemelerine olanak sağladığı ("Roman Müzisyenler İstanbullularla Buluşuyor", 2020), Muğla'da işçiler için müzik yapan Roman müzisyenlerin 1 Mayıs marşları söyleyerek evden çıkamayan işçilerin bayramını kutladığı ("Muğla'da Roman Müzisyenler", 2020), Roman müzisyenlerin Çanakkale Lapseki Belediyesi tarafından ilahi grubu olarak görevlendirildiği ("Roman İlahi Grubundan", 2020) haberlere yansımıştır. Merkezi ve yerel yönetimlerin Roman toplulukların dertlerine çare olamadığı gibi istihdam yaratıldığı izlenimini üretmeye dönük edimleri, kısa süreli, geçici gelir kaynağ1 sağlamanın ötesinde Romanların yapısal sorunlarına cevap üretecek nitelikte değildir. Türkiye görsel-işitsel medyasındaki Roman temsillerini irdeleyen Tunç Cox ve Uştuk (2019, s. 176), Romanların, Roman olmayanların görsel zevki için "egzotik ötekiler" olarak görünür kılındıklarını, öte yandan konut sorunu, yoksulluk, işsizlik, eğitimsizlik ve dışlanma gibi somut problemleri söz konusu olduğunda ise görünmez kılındıklarını göstermişlerdir. Film ve dizilerdeki temsil biçimlerine odaklanan bu çalışmanın tespitleri, haber metinleri söz konusu olduğunda da anlamlıdır. Sonuç olarak, merkez medya kuruluşlarının Romanların Türkiye genelinde deneyimledikleri yapısal sorunları ve ekonomik eşitsizlikleri gizleyerek sermaye ve iktidar odakları ile suç ortaklığını sürdürdüğü açıtır.

\section{Gündelik Hayatın Dönüşümü ve Irkçı Söylemlerin Yükselişi}

Romanların yaşam alanları, fiziksel altyapı ve nüfus yoğun yapıları nedeniyle salginla mücadelede risk alanları olarak tarif edilmektedir. Roman yerleşkelerini ele alan haber metinlerinde, ailelerin tek veya iki odalı hanelerde kalabalık bir şekilde yaşadıkları, birçoğunun tuvalet ve banyolarını komşuları ile ortak kullandıkları (Giritli İnceoğlu, 2020) yazılmıştır. Evlerin yapısal 
yetersizlikleri nedeniyle salgın başlamadan bile bir takım kronik rahatsızlıklara sebebiyet veren yaşam şartları altında (Giritli İnceoğlu, 2020), pandemi ile mücadelede en etkili strateji olarak öne sürülen "sosyal mesafenin" korunmasının imkânsız olduğu (Tok, 2020) vurgulanmıştır. Meskenlerin fiziksel özelliklerinin, gündelik etkileşim biçimleri üzerindeki etkileri de Romanların "iç içe yaşadıkları" vurgusu ile metinlere yansımıştır. "Romanlar için mahalle, mahalle olmanın ötesinde bir evin salonu gibi", "salonun her köşesinde birbiriyle temasları var" ("Kağıt ve Hurda Toplayan Romanlar", 2020) gibi benzetmeler aracılığıyla salgının gündelik hayat ile ilişkisi tarif edilmeye çalışılmakta, ancak bir yandan da Roman gündelik hayatına dair stereotipik imgeler yeniden üretilmektedir. Bu temsiller, Romanların "yaşam biçimlerindeki heterojenliği ve çeşitliliği görünmez kılarak onları tek bir etno-kültürel çerçeve içerisine hapsetmektedir" (Uştuk, 2021, s. 158). Benzer biçimde, yasaklara rağmen çocukların evlerde duramadıklarını ve sokağa çıkma ihtiyaçların (Arık, 2020) vurgulayan haberler, Romanların salgın için bir risk faktörü olarak görülmelerine sebebiyet verebilmektedir. Romanların "sosyal mesafe" önlemlerine uyamamaları, kültürel yaşam biçimleri üzerinden etnik kimlikleri ile ilişkilendirilerek ırkçı söylemleri ve ayrımcı pratikleri körüklemektedir. Örneğin bazı mahallelerin '"Romanlar zaten virüslü' denilerek ilaçlanmaması" ("48 Örgütten Ortak Açiklama", 2020), Romanları kentsel mekândan temizlenmesi gerekenler olarak imleyen ırkçı söylem ve pratikleri açık etmektedir. Mary Douglas, Nelkin ve Gilman'ın, modern çağda hastalıklara yönelik geliştirilmiş sofistike ve bilimsel kavrayışa rağmen halen davranış, etnisite ve sosyal stereotiplere dayalı basit açıklamalara yaslanıldığına yönelik tespitlerini hatırlattıktan sonra, sosyal stereotiplerin üretilmesinin sadece eski kafalılık ya da ilkellik ile ilişkili olmadığını vurgular (1994, s. 35). Bu süreç, toplulukların düzen empoze ederken bazı kimlikleri, bulundukları yere ait olmayan (out of place) olarak kodlamaları ve o kimlikleri kirli, haliyle tüm toplum için tehlikeli olarak nitelendirmeleri ile gerçekleşir. Doğal olarak bu gruplar toplum içinden "süpürülüp" temizlenmelidir (Douglas, 1966, s. 161). Bu tespitlerden hareketle, haber metinlerinin de Romanları ister istemez kirli ötekiler olarak kodladığı ve bu kodlamanın ırkçı söylemler ve pratikler üzerinden yankı bulduğu söylenebilir.

Bu kodlama süreci, ırkın kentlerde sınıfsal ayrım kadar derin çatlaklar oluşmasına ve mekânsal ayrıştırmanın artmasına sebep olmaktadır. İzole edilmiş kentsel alanlar istihdam imkânlarının yok olduğu mekânlara dönüşmektedir. Bu hali şiddetlendiren diğer bir etken ise pandemi sürecinde yürürlüğe koyulan sokağa çıkma yasaklarıdır (Davies ve Imbroscio, 2017, s. 360- 
379). Sokağa çıkma yasakları, gündelik hayatı ev içine kapatarak Romanlar başta olmak üzere birçok dezavantajlı kesimin kamusal mekânda gerçekleştirdikleri kayıt dişı ekonomik faaliyetlerini sekteye uğratmıştır. Küresel salgından etkilenen tüm ülkelerde, evinde kalabilen veya evden çalışanlar ekonomik kriz sürecini görece daha dengeli bir şekilde atlatabilirken, ekonomik etkinlikleri kamusal kentsel mekâna bağlı olan kesimler ise açlık sınırında yaşamaktadır (Fusch, 2020, s. 387). Kayıt dişı iş alanlarında çalışan insanların çoğu için sokak bir istihdam mekânıdır. Haliyle kısıtlamalar, hastalık kapmak ile aç kalmak arasında bir tercih yapma zorunluluğu meydana getirmektedir. Dezavantajlı grupların sokaktaki ekonomik faaliyetlerine devam etmek zorunda kalması ise, sokakların daha çok kontrol altında tutulmaya başlamasına sebep olmaktadır. Bununla birlikte sokağa çıkan insanların sayısının da azaltılması, sokak satıılarının kazançlarını da sekteye uğratmaktadır (Honey-Rosés ve diğerleri, 2020, s.3). Bu durum haberlere, Romanların "halk sağlığını korumak adına evden çıkamadıkları" ve "iş yerlerinin kapanması yüzünden gelir elde edemedikleri" (Giritli İnceoğlu, 2020) şeklinde yansımıştır. Öte yandan yasak ihlallerine yönelik cezaların da yoksul kesimler üzerinde ayrı bir baskıya dönüştüğü haberlerden izlenebilmektedir. Örneğin Roman bir kadının "sokağa çıkma yasağını ihlal ettiği için kendisine ceza kesildiği" ve "cezayı ödeyecek gücü olmadığı için yetkililerden cezayı affetmelerini" istediğinin haberi (Arık, 2020) ve ardından çocuklarına yemek hazırlayabilmek için çöpten yiyecek aramak zorunda kalan Roman bir annenin görüntüleri gündeme gelmiştir. Bu görüntülere İstanbul İl Müdür Yardımcısı Nail Noğay'ın Twitter üzerinden "geber" yazarak yanıt vermesi, STK'lar arasında büyük yankı uyandırmıştır. Medyada artmakta olan ırkçı söylemlere karşı tepkilerin büyümesi, Noğay'ın görevden alınmasıyla sonuçlanmıştır ("STK'lardan Ortak Açıklama", 2020). Ancak Noğay'ın tepkisi Türkiye'de etnik gruplara dair nefret söylemleri düşünüldüğünde tipik bir örnektir. Gerek emek biçimleri gerekse de Roman mahallelerinin nüfus kompozisyonu düşünüldügünde, salgın adına alınan önlemlerin Roman topluluklarını aç kalmak ile yasak çiğnemek arasında çelişkili bir duruma ittiği açıktır. Bu şartlar altında hayatta kalma mücadelesi veren kesimlerin yaptığı tercihlerin, imtiyazlı grupların şartlarına sahipmiş gibi düşünülerek yargılanmaları, yoksulluğun yükünün toplumsal eşitsizliklerin kurbanı olan kesimlerin sırtına yüklenmesine sebebiyet vermektedir. Kurbanı suçlayan söylemler, salgın kısıtlarına yönelik ihlalleri, Romanların kültürel yaşam biçimi ile ilişkilendirerek yarattı̆̆1 ırkçı temsiller aracılığıyla sınıfsal eşitsizliklerin de üzerini örtmektedir. 


\section{Medyanın Gözünden Roman Yerleşkelerindeki Tahribat}

Türkiye'de Roman yerleşkelerine yönelik müdahalelerin sayısız örneğine tanıklık edilmiştir. Ankara'da Çinçin, İstanbul'da Kuştepe, Küçükbakkalköy, Gültepe, Yahya Kemal ve Sulukule, Gaziosmanpaşa, Cebece, Zonguldak'ta Müftü ve Bursa'da Kamberler (Fundación Secretariado Gitano, 2010, s. 14) kentsel dönüşüme maruz kalan mahallelerden birkaçıdır. AKP hükümeti döneminde yürütülen kentsel dönüşüm projeleri, Toplu Konut İdaresi ve belediyeler arasında kurulan işbirlikleri ve 10-15 yıl vadeli ödeme planları üzerinden kurgulanmaktadır. Bu kurguda belirlenen yüksek ödeme oranlarının (Advisory Group on Forced Evictions, 2009, s. 49), kayıt dış1 ekonomilerin istikrarsız şartlarını dikkate almadan hesaplanması, birçok yoksul kesimin temel barınma haklarının gasp edilmesine neden olmaktadır (Akkan ve diğerleri, 2011, s. 37). Bu 15 yıllık süreçte "Roman mekânları, 'daha iyi bir yaşam' adı altında meşrulaştırılan dönüşüm projeleri aracilığıyla ivedilikle ortadan kaldırılması gereken bir alan olarak" (Akkan ve diğerleri, 2011, s. 38) tarif edilmeye başlanmıştır. İzmir' in Çeşme ilçesinde, bir kısmı sürekli olarak ikamet eden, bir kısmı ise yıllardır sezonluk olarak çalışmaya gelen ("Çeşmedeki Yıkımlara Tepkiler", 2020) Romanların barınma ihtiyacını karşılamak için kurdukları 300 çadırın kaymakamlığın izni dâhilinde Çeşme Belediyesi tarafından Romanlara yeterli süre verilmeden ve alternatif yaşam alanı üretilmeden yıkılması son 15 yıllık süreçte yaşanan dönüşümün bir çıktısıdır. Bu tahribatın medyada büyük ölçüde yer bulması, sivil toplum kuruluşlarının yanı sıra (Ürgir, 2020) yerel ve merkezi yönetimler arasında da yankı uyandırmıştır ("Çeşme'de Romanlara Ait Çadırlar", 2020). Bu bağlamda, İzmir Ak Parti Milletvekili Cemal Bekle'nin Çevre Şehircilik Bakanı Yardımcısı Fatma Varank ile çadırların kaldırılması hakkında görüşmesi "evsiz kalan vatandaşlarımızın sorununa acil çözüm bulmak konusunda istişare ettik" şeklinde haberlere yansımıştır ("Çeşme'de Romanlara Ait Çadırlar", 2020). İzmir CHP Milletvekili Cemal Purçu, Roman STK temsilcileri ve Çeşme Belediye Başkanı'nın bir arada yaptığı görüşmeler ise medyada "sonucun tatliya bağlandığı", "konu hakkındaki yanlış anlaşılmaların düzeltilmesi için gereken hassasiyetin gösterileceği", "kısa zamanda çözüme kavuşturulacağı" ve "mağduriyetin giderileceği" ifadeleriyle yer almıştır ("Çeşme'deki Roman Çadırları", 2020). "Tatlıya bağlandı" olarak lanse edilen bu süreç ("Çeşme'deki Roman Çadırları", 2020) başka kaynaklarda "hak ihlalinin gerçekleştiği" (Karadă̆, 2020) vurgusu ile yer almıştır. Bu olayın, Romanların zor durumda bırakılarak pandemi döneminde "yaşam mücadelesi vermesine" sebep olduğu 
("Çeşme' de Çadır Operasyonu", 2020) şeklinde metinlere yansımıştır. Çeşme Belediyesi'nin uyarı yapmadan yıkım gerçekleştirmesiyle Romanların "yetkililerin kendilerine yıkım yapılmayacağına dair verdiği sözü tutmadığı"na vurgu yapılmıştır ("Çeşme' de Romanların Çadırları", 2020). Bunun yanı sıra, yıkım sürecinde Romanların "sinir krizi geçirdiği", "direndiği" ve "haklı direnişe" karşı "gözaltına alındığı" ifadeleri de metinlere yansımıştır ("Çeşme'de Çadır Operasyonu", 2020). Haberlerin genel görünümü üzerinden yapılan değerlendirme sonucunda, Romanların yaşam alanında gerçekleştirilen tahribatın siyasi aktörleri ön plana çıkaran ve çoğunlukla yaşanan zorlukları ikinci plana atan bir kurguya sahip olduğu söylenebilir. Bu haberlerin çoğu, yaşanan tahribata ivedi çözümler üretildiği yanılsamasına yönelik bir dil ile kurgulanmıştır.

Çadırların yıkımı ile sert ve acımasız bir şekilde yapılan tahribatı konu alan haberlerin yanı sıra, kentsel mekânın uzun vadede dönüşümüne işaret eden haberler de bu ve benzeri yıkım süreçlerinin gelecekte de devam edeceği izlenimini yaratmaktadır. Şehirleri homojenleştiren neoliberal kent politikalarının gündelik hayat üzerindeki etkisi pandemi ile birlikte hızlanmaktadır (Salama, 2020, s. 9). Bu politikaların, düşük gelir grupları yerinden etme eğilimi, hâlihazırda ırkçılık yüzünden ayrıştırılan gruplarda daha derin ayrımlara sebep olmaktadır (Gilmore, 2002, s. 16). Soylulaştırma ile düşük gelirli kesimlerin ikamet ettiği kentsel mekânlar, varlıklı kesimlere devredilmektedir (Van Criekingen ve Decroly, 2003, s. 2454). Türkiye'de soylulaştırma projelerinden en çok etkilenen gruplardan biri olan Roman mahalleleri, mekânsal ayrıştırmanın en görünür örneklerini teşkil etmektedir. Kent merkezlerinde sosyo-ekonomik ve sağlık açısından steril ortamlar yaratılması amacı doğrultusunda mahalleler kapatılarak, Romanlar her geçen gün kent merkezlerinden daha da uzaklaştırılmaktadır.

Yerel yönetimlerin imar planları ile ilgili çalışmalarının pandemi döneminde de duraksamadan devam ettiğine yönelik haberler ("Akdeniz' de Toki ile Pazarlık", 2020) gelecekte de yıkım, yerinden edilme ve homojenleştirme çabalarının hız kaybetmeden devam edeceği mesajını taşımaktadır. Hedeflenen dönüşüm hususunda "Romanlar ile mutabakata varıldığı, müteahhitler ile Romanların buluşturulduğu", bu dönüşümlerin yerinden edilme süreci ile sonuçlanmayacağı aksine Romanlar için daha iyi yaşam şartları sağlayacak bir kentsel mekânda ikamet etme firsatı yaratılacağı (Boğazlıyan, 2020) iddialarına Romanlar arasında itibar edilmemektedir. Haber Türk'ün internet sitesinde bulunan, "Proje, bölgede yaşayan Roman yurttaşların düşünceleri dikkate alınarak katılımcı bir süreçle yapıldı" ("Ege Mahallesi'nde Dönüşüm", 
2020) ve "Ege Mahallesi'ndeki Roman vatandaşların kentsel dönüşümü için projeyi hazırladık, tapularının mutabakatını aldık" (Boğazlıyan, 2020) ifadelerinin yer aldığı haberlerde, Roman mahallelerindeki tahribatın gizlendiği ve kentsel dönüşümün yarattığı olumsuz etkilerin göz ardı edildiği görülmektedir. Bu bağlamda, bir taraftan mevcuttaki kamusal açk alanlar yakın çevresindeki konut değerini yükseltmekte, öte yandan yeni yapılan konut projelerinde kapalı sitelerin kullanımı için özelleşmiş açık alan tasarımlarına verilen önem artmaktadır. Dolayısıyla, açık alanlar bir pazarlama aracı olarak kullanılmakta ve soylulaştırma aracı haline gelmektedir. Mega konut projelerinin, özel amaçı kullanıma hizmet eden açık alanlara sahip olması da, bu projelere talebin artacağının ve dezavantajlı grupların yakın gelecekte artan oranlarda yerinden edilmeye maruz kalacağının emarelerini barındırmaktadır. Bir başka deyişle pandeminin kentsel mekâna hâkim olması, yoksulluğun yanı sıra adaletsizliği de derinleştirmektedir (Anguelovski ve diğerleri, 2020, s. 1761).

\section{Siyasal Aktörlerin Propaganda Aygitı}

Bir propaganda aracı olarak merkez medya, "iktidarların varlıklarını sürdürebilmeleri ve otoritelerinin devamlılığını sağlayabilmeleri için" (Biber ve Turancı, 2014, s. 39) elzem bir kaynaktır. Bu kaynağın kullanımı siyasetçilerin yanı sıra dernek başkanları, sivil toplum kuruluşları gibi çeşitli aktörler için de önemlidir. Bu çalışma kapsamında incelenen haberlerde merkez medyanın, siyasi aktörleri metnin merkezine aldığı ve Romanlara dair gündemi siyasi propaganda ya da reklam firsatı olarak araçsallaştırdığı görülmüştür. Öte yandan dernek ve sivil toplum kuruluşlarının medya kanalları, Romanların sorunlarını merkeze alan metinler üretmeye daha yatkındır, buna karşın bu medya kanallarının birer aktör olarak kendilerini Romanlardan daha fazla ön plana çıkardığı metinler de azımsanmayacak ölçüdedir.

Bu bağlamda İzmir Romanlar Sosyal Yardımlaşma ve Dayanışma Derneği Başkanı Abdullah Cıstır "yetkililerden pozitif ayrımcılık bekliyoruz", "insanlar bizi öcü gibi görmesin" sözleriyle gündeme gelmiştir ("Dernek Başkanı'ndan Roman Mahalleleri", 2020). Marmara Bölgesi Roman Dernekleri Federasyonu Sinan Karaca Öztürk ise "Devlet sahip çımıyor, yerel yönetimler sahip çıkmıyor" diyerek Roman mahallelerine yapılan yardımların medyaya yansıtıldığı biçimde kapsamlı olmadığını iddia etmiştir (Kaya, 2020).

Dernek başkanlarının yanı sıra STK'lar aracılığıyla oluşturulan projeler kapsamında da Romanların medyada seslerini duyurmaya çalıştı̆̆ı görülmektedir. Özellikle Roman Diyalog Ağının Güçlendirilmesi Projesi (RODA) 
iki farklı habere konu olmuştur. $\mathrm{AB}$ finansmanındaki bu proje çerçevesinde hükümet dışı kurumlarla bir araya gelinerek, Roman kadınların yaşadığı sorunlara çözüm aranması hedeflenmiştir (Tokyay, 2020). Bu bağlamda Roman kadınlarla birçok görüşme yapılmış, bu proje sayesinde Roman kadınların "Biz de buradayız..." diyerek bir araya geldiği belirtilmiştir (Nida, 2020b). S1fır Ayrımcılık Derneği kapsamında hazırlanan "Roman Kadınlar Anlatıyor: Duymadıklarımızı" adlı belgeselde, Roman kadınların gündelik hayatına odaklanılarak, pandemi şartlarında çektikleri zorluklar konu alınmıştır ("Roman Kadınlar Anlatıyor", 2020). Bunun yanı sıra, Roman aktivist Nilay Karadeniz'in, Edirne'de yaşayan Roman kadınlara yönelik artan şiddet olaylarından ötürü İstanbul Sözleşmesi'ni anlatması da "ev ev dolaşarak Roman kadınlara İstanbul Sözleşmesi'ni anlatıyor" başlığı ile haberlerde yer almıştır (Nida, 2020a).

Projelere ek olarak Romanların medyada seslerini duyurma mücadelesinin, toplu eylemler doğrultusunda da devam ettiği görülmektedir. Sakarya'nun Gevye ilçesindeki Romanların, "Cumhurbaşkanı Recep Tayyip Erdoğan'ın 'ihtiyacı olan hiçbir vatandaşımız yardım istemekten çekinmesin' ifadesi üzerine" kaymakamlık önünde toplanarak yardım istemesi sonucunda "emniyet güçlerinin müdahalesiyle kaymakamlık bahçesinden çıkarılması" haberleştirilmiştir (Kaytanbay, 2020). Aydın'ın Nazilli ilçesinde yaşayan Roman müzisyenlerin, "kaymakamlıktan destek istiyoruz" çağnısı ise "Nazillili davulcular destek bekliyor" başlığı ile haberlere yansımıştır (Kılıç, 2020). Bunların yanı sıra "Cumhurbaşkanı Recep Tayyip Erdoğan'ın başbakanlığı döneminde başlatılan 'Roman Açılımı'nın, 2021 yılına kadar devam edeceği öngörülse de, üzerinden 10 yıl geçmesine rağmen Romanların yoğun yaşadığı illerden biri olan Edirne'deki bazı Roman vatandaşların evlerine hiç uğramaması" (Akagündüz, 2020) haberlerde dikkat çekilen konular arasında yer almıştır.

Pandemi koşullarında birçok haber, Romanların yaşadıkları zorlukları dikkate almadan, siyasetçileri özne kılan metinlerin de çeşitli örneklerini sunmuştur. Örneğin, "TBMM Başkanı Mustafa Şentop, iki Roman milletvekilini ve Tekirdağ'daki Roman sivil toplum kuruluşlarının temsilcilerini arayarak Dünya Romanlar Günü'nü kutladı" ifadeleriyle gündemde yer almıştır (Akan, 2020). Romanların gündelik hayattaki sorunlarına değinmeyen bu haberlere bir diğer örnek, Roman müzisyenlerin İzmir Belediye Başkanı için hazırladığı doğum günü kutlamasına istinaden Tunç Soyer'in, "İzmir Romanlarla güzel" ifadeleriyle haberlere konu olmasıdır ("Buca Gaziemir ve Çiğli'ye Maskematik", 2020). Yine bu minvalde, Mersin'de yaşayan Romanların "kül- 
türlerini yaşayabilecekleri, ayrıca el emekleriyle elde edilen sanatsal ürünlerini sergileyebilecekleri bir alan ve yer sağlanmasını içeren komisyon raporlarının oy birliğiyle kabul edilmesi" ("Başkan Gültak'tan Pandemi Uyarısı", 2020), CHP Genel Başkan Yardımcısı Fethi Açıkel başkanlığında "Romanlar İçin Yoksulluk ve Ayrımclık Kader Olmasın: En Canlı Renklerimiz Solmasın" başlıklı bir "politika notu" hazırlanması, "Aile Yardımları Sigortası'nın en etkin uygulama olarak kullanılmasının" hedeflenmesi (Yıldızalp Özmen, 2020), Romanların bir araya gelerek "Güzel Parti" adıyla bir siyasi parti kurması ve Hüseyin Akbulut'un genel başkan olması ("Roman Partisi Resmen Kuruldu", 2020) siyasetçileri özne kabul ederek metni kuran ve gündemi araçsallaştıran örnekler olarak karşımıza çıkmaktadır. Haber metinlerinin bu araçsallaştırmayı en çok açık eden yönü ise, gerek sorunlar gerekse de çözüm önerileri konusunda net çalışma planı ihtiva etmeyen muğlak ve genel ifadeler ile kurulmuş olmasıdır. Örneğin "Zonguldak Valisi Mustafa Tutulmaz katılımcılara ve paydaşlara hitaben yaptığı konuşmada, eylem planında kendilerine görev düşen kurum ve kuruluşların, Roman vatandaşlarımızın karşılaştıkları sorunlara duyarlı davranarak samimiyetle, içtenlikle ve adanmışlık duygusuyla yaklaşmalarını ve üzerlerine düşen görev ve sorumlulukları hassasiyetle yerine getirmelerini istedi" ifadeleri kullanılmıştır (Yılmaz, 2020). Edirne'deki eylem planı ise manşetlerde "Eylem planını hazırlayan ilk ve öncü il Edirne oldu" ifadeleriyle yer bulmuştur (Ceylan, 2020).

Siyasi aktörlerin medyadaki görünürlüklerini arttırmak adına Roman mahallelerine yaptıkları ziyaretler ve yardımlar üzerinden sıkça haberleştirildiği görülmektedir. Bu bağlamda, İzmir CHP Milletvekili Özcan Purçu'nun, İzmir Örnekköy'deki Roman mahallelerine erzak yardımında bulunması, haberlere "Çocukların ve ailelerin yüzünü güldürdü" başlığı ile yansımıştır ("Örnekköy'de Örnek Mesai", 2020). Bir başka haberde Purçu, "Yüzlerce aileye erzak dağıtan Purçu koronavirüste müzisyenlerin Korona şarkısı eşliğinde erzak dağıtarak farkındalık yaratmaya çalıştıklarını söyledi" ("Roman Milletvekili Purçu'dan", 2020) ifadesiyle ön plana çımaktadır. Mersin'de yapılan çorba yardımı, medyada "Mersin Büyükşehir Belediyesi'nin sıcak çorbası ile gün aydınlandı ve insanların yüzleri güldü" ifadeleriyle yer almıştır ("Roman Mahallesinde Gün", 2020). Çağdaş Kocaeli adlı haber kaynağında ise "Ulaşamadığımız kimse kalmasın istiyoruz" şeklinde iddialı bir başlık ile sunulan haberde "Gönülden Gönüle" adlı proje kapsamında İzmit Tavşantepe Mahallesi'ni ziyaret eden Kocaeli valisinin "Ulaşamadığımız her insan bizim için kayıptır", "bu şehirde yaşayan herkese ve her kesime ulaşmayı hedefliyoruz" sözlerinin altı çizilmiştir ("Ulaşamadığımız Kimse Kalmasın", 2020). 
Tüm bu haber metinlerinde siyasi aktörlerin Romanların gündelik hayatı ile kurduğu ilişkinin yereli ve yerel deneyimi temsil etmekten uzak olduğu görülmektedir. Öte yandan sivil toplumun çeşitli kanallarından yürütülen projelerin yerel gerçeklikler ile görece daha temas içinde olduğu söylenebilir. Ancak Romanlara yönelik tasarlanan eylem planlarının çoğunun mahalle ölçeğine inmediği görülmektedir. Yerel yönetimlerin pandemi sürecinde Roman aileleri desteklemek adına yaptı̆̆ küçük çaplı yardımların medyada sürekli dolaşıma sokulduğuna şahit olsak da, günübirlik ve temel ihtiyaçlara ancak cüzi miktarda yanıt verebilecek bu yardımların, siyasetin malzemesi olmaktan öteye geçememesinden dolayı yoksulluğa çözüm üretme yönünde gelişme kaydedilmesi de mümkün olmamaktadır.

\section{Sonuç}

Koronavirüs salgınının Romanların yaşam alanları, ekonomik etkinliklerini sürdürdüğü kamusal alanlar ve yerel yönetimler ile ilişkileri üzerinde önemli etkileri olmuştur. Bu etkileri eleştirel söylem analizi yöntemi ile ele alan bu çalışmada, gündelik hayatın dönüşümü haber metinleri üzerinden izlenmiştir.

Pandemi ile derinleşen yoksulluğun etkilerini irdeleyerek bir çerçeve çizilen bu çalışmada ilk olarak Romanların yoksulluk deneyimlerinin medyada nasıl dolaşıma girdiği incelenmiştir. Bu inceleme haber metinlerinde Roman temsillerinin iki şekilde kurulduğunu göstermiştir. Birincisi pandeminin olumsuz etkilerini ele alarak Romanları kent yoksulları olarak özne kılan metinler, ikincisi ise Romanları kültürel imgeleri ile metalaştırarak nesneleştiren ve kimliklerinden ötürü deneyimledikleri yapısal eşitsizlikleri gizleyerek toplumsal mecrada bir "renk" olarak kodlayan metinlerdir. "Tüketim kültüründe etnisitenin sıkıcı anaakım kültürü renklendirerek" (hooks, 2015, s.44) bir tüketim nesnesine dönüşme eğilimi haber metinlerinde açıkça izlenmektedir. hooks'un analizinden hareketle anaakım toplumun kendi kimlik kriziyle başa çıkarken başvurduğu özne ve nesneyi ayırma ihtiyacı (hooks 2015, s. 45) bu metinlerde kendini göstermektedir.

Çalışmanın ikinci analiz teması gündelik hayatın dönüşümüne eşlik eden ırkçı söylemlerdeki artışa odaklanmaktadır. Bu söylemler genel olarak pandemi yasaklarını ihlal etmek durumunda kalan Romanların davranışlarını Roman kültürü ve genel olarak etnik kimliği ile ilişkilendirerek izah eden bir imge üretimi aracılığıyla ırkçı söylemlere zemin hazırlamaktadır. Romanların anaakım topluma ait olmayan ötekiler olarak kodlandığı için kent mekânından temizlenmesi gereken bir grup olduğu algısı üretilmekte ve bu algı kentsel soylulaştırmanın gerekçesi olarak karşımıza çıkmaktadır. 
Üçüncü olarak çalışma, kentsel soylulaştırma gerekçesi ile Romanların yaşam alanlarında gerçekleşen tahribata odaklanmaktadır. Merkezi ve yerel yönetimlerin gerek TOKİ gerekse de mega projelere yönelik neoliberal kent politikaları ekseninde Roman vatandaşların kent merkezlerinden uzaklaştırılmasının, "daha iyi bir yaşam" vaadi ile gerekçelendirildiği ancak sadece var olan yoksulluğu derinleştirdiği anlaşılmıştır. Pandemi önlemleri çerçevesinde kontrol altına alınan kamusal mekânlarda ise ayrımcllığın arttığı, bu durumun da ırkçılık yönelimlerini arttırdığı görülmektedir (Honey-Rosés ve diğerleri, 2020, s. 10). Tek kültürlü homojen yapının kamusal mekânlara hâkim kılınmasına yönelik eğilimler, mekânın kamusallığını ve demokratik olma özelliğini yok etmekte, marjinal grupların mekânı özgür kullanımını olumsuz etkilemektedir (Landman, 2020, s. 212-213).

Son olarak siyasal aktörlerin Romanların yaşam mücadelesini kendi gündemlerini oluşturmak adına araçsallaştırmaları çerçevesinde kurgulanan metinlerin eleştirel bir okuması yapılmıştır. Siyasi figürlerin ve bazı STK'ların mahallere yaptıkları ziyaretler ve yardımlar üzerinden görünürlüklerinin arttığı ve haber metinlerinin özneleri olarak metinlerde merkezi bir yer buldukları görülmüştür. Romanlar ise metinlerde, bu yardımların pasif alıcıları olarak ya "günleri aydınlanan" ve "yüzleri gülen" bireyler olarak nesneleştirilmekte ya da hiçbir şekilde yer almamaktadırlar.

Romanlara yönelik tasarlanan eylem planlarının çoğunun mahalle ölçeğine inmediğine ve pandemi sürecinde Roman aileleri desteklemek adına yerel yönetimlerin yürüttüğü küçük çaplı yardım kampanyalarının sürekli dolaşıma sokulduğu görülmüştür. Temel ihtiyaçları karşılamakta bile yetersiz kalan bu yardımların akıbetinin Romanların gündemden düştüğünde ne olduğu ise belirsizdir. Nihayetinde yardımlar, yoksulluğu üreten yapısal eşitsizliklere yönelik bir çözüm üretmekten ve "emniyet supabı" (Coser, 1956, s. 45) işlevi görerek kamusal vicdanı kısa süreliğine sağaltmaktan öte bir sonuç vermemektedir.

Marjinal grupların yaşadığı bölgelerdeki sorunlar yeni değildir. Ancak pandemi hali, bulaşıyı azaltmanın aciliyetiyle dezavantajlı mekânlar için yenilikçi çözümler üretilmesini gündeme taşımıştır (Golechha, 2020, s. 796). Buna karşın akademik mecralarda üretilen çözümler, merkezi ve yerel yönetimlerin gündemine yeterince yansımadığı gibi, kalıc eylem planları da üretmemektedir. Pandemi ile mücadelede, dirençli toplumlar inşa etmek için sosyo-ekonomik dezavantajları azaltmanın önemi bir kez daha belirgin hale gelmiştir. Virüsün sınıf tanımadığını görmenin toplumsal adaletsizliklere karşı bir farkındalık yaratacağına yönelik romantik eğilimlerin ise neoliberal 
kent politikalarının altında ezildiğini söylemek mümkün. Umut edilen farkındalık bir yana, pandemi koşullarındaki hayatta kalma pratikleri nedeniyle Romanların günah keçisi ilan edilmelerine aracılık eden metinler bizi Roman kültürel kimliğini dolayımlayan güç ilişkilerinin nesnel analizinden uzaklaştırmakta ve alan tanıdığı ırkçı söylemler aracılığıyla mevcut durumun üzerini örtmektedir. Sürdürülebilir ve dirençli bir toplum hayali adına, altyapı, sağlık, eğitim, istihdam, barınma gibi hizmetlerden dezavantajlı grupların adaletli bir şekilde yararlanmalarına yönelik tedbirler alınmadığı sürece olası mağduriyetin, sadece bu grupların iç dinamikleri açısından değil aynı zamanda genel toplum sağlığı, toplumsal iletişim ve gelişim açısından da tehdit oluşturacağı hesaba katılmalıdır. Sürdürülebilir toplumsal politikaların üretilmesi anlamında bir ülkenin dezavantajlı gruplarının dikkate alınması gerektiği aşikârdır. 


\section{Extended Abstract}

\section{Media Coverage of the Transformation of Everyday Life of Roma Communities during Covid-19 Pandemic}

\author{
Ozan Uştuk \\ ORCID: 0000-0002-4062-8404
}

\author{
Ece Güleç \\ ORCID: 0000-0002-2725-863X
}

This study examines the transformation of the everyday life of Roma communities during the Covid-19 pandemic through media coverages by focusing on their living spaces, public spaces where they continue their economic activities and build their relations with local governments. The observations cover that the daily rhythms, routines, and rituals of communities in the struggle for survival, are deeply shaken to the core because of the pandemic conditions in poor living spaces. Therefore, it can be said that the pandemic reveals social inequalities that are taken for granted. Affected adversely as a result of the pandemic conditions, the Turkish Roma's daily lives are either unable to find enough coverage in the mainstream media or they are misrepresented due to the ideological affiliations of the media owners. Examining the culture-centered discourses revolving around the central and local governmental interventions towards the Roma living spaces amidst the pandemic and the relevant media exposure is herein essential so as to understand the power dynamics which takes place between Romani communities and political actors. Analyzing the culture-centered discourses circulated by the local and central governmental actors as a means to justify their policies towards urban space provides the opportunity to both evaluate the relationship between the Roma communities and political actors and to uncover hidden inequalities.

Employing a critical discourse analysis method, we have initially drawn a general framework about extreme poverty, and subsequently surveying the media coverage on the Roma people. Against this backdrop, we firstly looked at the media depiction of the Roma's experiences regarding extreme poverty. 
An analysis of the produced and circulated news regarding the Roma representations within the collaborative dynamics among the media, power, and capital, which becomes more of an issue what is said as much as what is left unsaid, as well as examining the causes are of great significance. Therefore, we examined 67 news containing the word "Roma" published between March 11, 2020, when the first case of the COVID-19 virus was announced in Turkey, and December 24, 2020. Two discourses on the Roma representations emerge that are poles apart in the news regarding the pandemic. The first discourse is focusing on the image of poverty in the Roma neighborhoods, aggravating because of the pandemic. The other discourse, disregarding the poverty dimension, centers the Roma people's cultural lifestyle via commodification of otherness and mask existing structural inequalities. Secondly, we interpreted the rise of racist discourses accompanying the transformation of everyday life and how are these discourses conceal inequalities regarding class inequalities. Ethnic identity herein becomes visible as a factor affecting access to healthcare services. This coding process causes deep racial rifts to form class division in cities, increasing socio-spatial segregation. The Roma living spaces are assessed atrisk areas in the fight against the pandemic because of the hard infrastructure and population density. That the choices made by those struggling for survival under these circumstances are judged as if they had the same conditions as those of the privileged causes burden of their poverty to be put on their shoulders. Furthermore, victim-blaming discourses mask class inequalities through racist representations, correlating violations of pandemic restrictions with the Roma cultural lifestyle. Thirdly, we investigated the damage caused by local authorities to the living spaces of Roma and the interrelation of these damages to neoliberal urban policies. Recent urban renewal projects rest on collaboration between the Mass Housing Development Administration (TOKI) and municipalities besides payment plans with a maturity of 10-15 years. The high payment rates calculated without considering the precarious conditions caused by the informal economy in this plan usurp the right to housing of many poor. The Roma living spaces have begun to be addressed as spaces that need immediate clear out through urban renewal projects in these 15 years. This indicates that disadvantaged groups will be increasingly exposed to displacement in the near future. Finally, we engaged a critical reading of the news, in which we noticed the struggle of Roma people is instrumentalized by political actors into their agendas. The news analysis reveals that the mainstream media centers its text around the political actors, instrumentalizing the Roma agenda as political propaganda or advertising opportunity. Media channels used by associations 
and non-governmental organizations, on the other hand, mostly tend to draw attention to the problems of the Roma. In spite of this, the texts in which these media channels mostly featuring themselves as actors more than the Roma are to a great extent. As for the Roma, they are either objectified as passive aid recipients or are not included at all.

To conclude, the problems faced by marginalized groups in their living spaces are not recent. However, the pandemic circumstances have brought working for innovative solutions in disadvantaged living areas to the agenda with the urgent need to reduce transmission. Academic solutions, on the other hand, do not bring the central and local governments up and do not produce effective action plans. The gravity of eliminating socioeconomic disadvantages to build resilient societies has once again become prominent. Threats of possible victimization will not only occur in the internal dynamics of these groups but also in terms of public healthcare and general welfare provided that precautions are not taken regarding the fair distribution of services such as infrastructure, healthcare, education, employment, and shelter for the disadvantaged groups. Thus, necessary precautions are of the essence to achieve a sustainable and resilient society. The socially disadvantaged groups evidently must be taken into consideration when it comes to developing sustainable social policies.

\section{Kaynakça/References}

48 Örgütten Ortak Açıklama Romanlar Virüsten Çok Açlıla Mücadele Ediyor. (2020, Nisan). Evrensel. Erişim adresi: https://www.evrensel.net/haber/401628/48-orgutten-ortak-aciklama-romanlar-virusten-cok-aclikla-mucadele-ediyor

Advisory Group on Forced Evictions. (2020). Mission to Istanbul. Erişim adresi: https://reclaimistanbul.files.wordpress.com/2011/04/2009-7-agfe-report-istanbul.pdf

Akagündüz, U. (2020, 15 Mayıs). Roman evine girmeyen açlım. Sözcü. Erişim adresi: https://www.sozcu.com.tr/

Akan, A. K. (2020, 8 Nisan). TBMM Başkanı Şentop, Dünya Romanlar Günü'nü kutladı. Anadolu Ajansı. Erişim adresi: https://www.aa.com.tr/

Akdeniz'de Toki İle Pazarlık Başlıyor. (2020, Temmuz). Haberci. Erişim adresi: https://www.mersinhaberci.com/haber/22831/akdenizde-toki-ile-pazarlik-basliyor.html

Akkan, B. E., Deniz, M. B. ve Ertan, M. (2011). Sosyal dışlanmanın Roman halleri. İstanbul: Punto Baskı Çözümleri.

Anguelovski, I., Brand, A. L., Connolly, J. J. T., Corbera, S. Kotsila, P., Steil, J., ... Argüelles Ramos, L. (2020). Expanding the boundaries of justice in urban greening scholarship: toward an emancipatory, antisubordination, intersectional and relational approach. 
Annals of the American Association of Geographers, 110(6), 1743-1769. doi:10.1080/24694452.2020.1740579.

Arık, V. (2020, 3 Mayıs). Küçücük evlere sığamayanlar. Cumhuriyet. Erişim adresi: https://www.cumhuriyet.com.tr/

Avcı, S (2020, 3 Haziran). Roman kadınların ellerinde şekillenen kamışlar enstrümana dönüşecek. Anadolu Ajansı. Erişim adresi: https://www.aa.com.tr/

Azar, K. M. J., Shen, Z., Romanelli R. J., Lockhart, S. H., Smits, K. Robinson, S. ... Pressman, A. R. (2020). Disparities in outcomes among Covid-19 patients in a large health care system in California. Health Affairs, 39(7), 1253-1262. doi: 10.1377/hlthaff.2020.00598

Baker, J., Cira, D. ve Lall, S. (2020). Covid-19 and the urban poor addressing those in slums. Erişim adresi: http://pubdocs.worldbank.org/en/304801589388481883/AddressingCOVID-19-and-the-Urban-Poor-SHORT-version-rev3-logos.pdf

Başkan Gültak'tan Pandemi Uyarısı: "Çember Çok Daraldı". (2020, Aralık). Haber Türk. Erişim adresi: https://www.haberturk.com/mersin-haberleri/82777531-baskan-gultaktanpandemi-uyarisi-cember-cok-daraldi

Berta, P. (2020) Ethnicizing a pandemic: Covid-19 culture blaming and Romanian Roma. Society for Romanian Studies Newsletter, 42(1), 13-16. Erişim adresi: https://society4romanianstudies.org/wp-content/uploads/2016/11/2020-Spring-Newsletter.pdf

Biber, A. ve Turanc1, E. (2014). Toplumsal şeytan üçgeni: İktidar, hegemonya ve propaganda. Akdeniz Üniversitesi İletişim Fakültesi Dergisi, (21), 28-41. doi: 10.31123/akil.442999

Boğazlıyan, E. (2020, 9 Ağustos). Tunç Soyer: İzmir şu anda en çok göç alan şehir. Haber Türk. Erişim adresi: https://www.haberturk.com/

Buca Gaziemir ve Çiğli'ye Maskematik. (2020, Mayıs). Milliyet. Erişim adresi:https://www.milliyet.com.tr/ege/buca-gaziemir-ve-cigliye-maskematik-6213181

Çamur Duyan, G. (2010). Yoksulluğun kadınlaşması: Altındağ örneği. Aile ve Toplum. 6(22), 19-29. Erişim adresi: https://dergipark.org.tr/tr/download/article-file/197990

Centers for Disease Control and Prevention. (2020). COVIDView a weekly surveillance summary of U.S. Covid-19 activity. Erişim adresi: https://www.cdc.gov/coronavirus/2019ncov/covid-data/pdf/covidview-07-31-2020.pdf

Çeşme' de Çadır Operasyonu! Belediye Hepsini Kaldırdı. (2020, Haziran). Yeni Asır. Erişim adresi: https:/www.yeniasir.com.tr/izmir/2020/06/16/cesmede-cadir-operasyonu-belediye-hepsini-kaldirdi\#: :text=de\%20\%C3\%A7ad\%C4\%B1r\%20operasyonu!-,Belediye $\% 20$ hepsini $\% 20 \mathrm{kald} \% \mathrm{C} 4 \% \mathrm{~B} 1 \mathrm{rd} \% \mathrm{C} 4 \% \mathrm{~B} 1$,direnen $\% 20$ bir $\% 20$ ki\%C5\%9Fi\%20g\%C3\%B6zalt\%C4\%B1na\%20al\%C4\%B1nd\%C4\%B1

Çeşme'de Romanlara Ait Çadırlar Söküldü. (2020, Haziran). Bianet. Erişim adresi: https://m.bianet.org/bianet/insan-haklari/225887-cesme-de-romanlara-ait-cadirlar-sokuldu

Çeşme'de Romanların Çadırları Kaldırıldı. (2020, Haziran). Milliyet. Erişim adresi: https:/www.milliyet.com.tr/gundem/cesmede-romanlarin-cadirlari-kaldirildi6236575\#: :text=Ala\%C3\%A7at\%C4\%B1\%20Mahallesi\%20\%C5\%9Eahin\%20Te- 
pesi $\% 20$ mevkisinde,ekip-

ler\%2C\%20kep\%C3\%A7e\%20deste\%C4\%9Fiyle\%20\%C3\%A7ad\%C4\%B1rlar\%C4\% B1\%20kald\%C4\%B1rd\%C4\%B1

Çeşme'deki 'Roman Çadırları Krizi' Tatlıya Bağlandı. (2020, Haziran). İzgazete. Erişim adresi: https://www.izgazete.net/politika/cesme-deki-roman-cadirlari-krizi-tatliya-baglandi-h49020.html

Çeşme'deki Yıkımlara Tepkiler Sürüyor. (2020). Roman Medya. Erişim adresi: https://www.romanmedya.org/cesmedeki-yikimlara-tepkiler-suruyor/

Ceylan, Ö. (2020, 11 Kasım). Koruyucu aile sıralamasında Türkiye'de ikinciyiz. Edirne Haber. Erişim adresi: http://www.edirnehaber.org/

Cole, H. V. S., Anguelovski, I., Baró, F., García-Lamarca, M., Kotsila, P., del Pulgar, Carmen., ...Triguero-Mas, M. (2020). The COVID-19 pandemic: power and privilege, gentrification, and urban environmental justice in the global north. Cities $\mathcal{E}$ Health. doi:10.1080/23748834.2020.1785176

Corburn, J., Vlahov, D., Mberu, B., Riley, L., Teixeira Caiaffa, W., Rashid, S. F. ... Ayad, H. (2020). Slum health: Arresting covid-19 and improving well-being in urban informal settlements. Journal of Urban Health, 97, 348-357. doi:https://doi.org/10.1007/s11524-02000438-6

Coser, L. A. (1956). The functions of social conflict. New York: Routledge

Costache, I. (2020, 22 Nisan). Until we are able to gas them like the Nazis, the Roma will infect the nation: Roma and the ethnicization of Covid-19 in Romania [Blog yazisı]. Erişim adresi: https:/www.dor.ro/roma-and-the-ethnicization-of-covid-19-in-romania/?fbclid=IwAR2zeDm6GKdfSQ3NArODqJP_hzpEYTLs807ZGuU8RSpGp_oWhTPqvg4

Davies, J. S. ve Imbroscio, D. L. (2017). Kentsel politika teorileri. İstanbul: Litera Yayıncllı.

Demirci, C. (2020, 27 Temmuz). Roman müzisyenler en çok oyu almak için maharetlerini sergiledi. Anadolu Ajansı. Erişim tarihi: https://www.aa.com.tr/

Depeli, G. (2013). Anayasa yazım sürecine LGBT müdahilliğinin merkez medyadaki görünümü. Galatasaray Üniversitesi İletişim Dergisi, (18), 38-60. Erişim adresi: http://iletisimdergisi.gsu.edu.tr/tr/download/article-file/82672

Dernek Başkanı'ndan Roman Mahalleleri İçin Pozitif Ayrımcılık Çağrısı. (2020, Ağustos). Gerçek İzmir. Erişim adresi: http://www.gercekizmir.com/haber/Dernek-Baskanindan-Roman-mahalleleri-icin-pozitif-ayrimcilik-cagrisi/84549

Douglas, M. (1966). Purity and danger. New York: Routledge.

Douglas, M. (1994). Risk and blame. New York: Routledge.

Ege Mahallesi'nde Dönüşüm Başlıyor. (2020, Ekim). İzmir Büyükşehir Belediyesi. Erişim adresi: $\quad$ https://www.izmir.bel.tr/tr/Haberler/ege-mahallesi-nde-donusum-basliyor/44198/156

Erbalaban Y1lmaz, E. (2020, 28 Ağustos). Pandemi döneminde Roman havası estirdiler. Anadolu Ajansı. Erişim adresi: https://www.aa.com.tr/

Fuchs, C. (2020). Everyday life and everyday communication in coronavirus capitalism. tripleC, 18(1), 375-379. doi: https://doi.org/10.31269/triplec.v18i1.1167 
Fukuda-Parr, S. (1999). What does feminization of poverty mean? It isn't just lack of income. Feminist Economics, 5(2), 99-103. doi:https://doi.org/10.1080/135457099337996

Fundación Secretariado Gitano. (2010). Türkiye'de Romanların durumu Türkiye'de çalışma ve insana yakışır iş koşulları sorunlan (Sözleşme Referans No. VC/2009/0365). Erişim adresi: http://www.errc.org/uploads/upload_en/file/turkey-understanding-employmentand-decent-work-challenges-in-turkey-december-2010-turkish.pdf

Gay y Blasco, P. ve Rodriguez Camacho, M. F. (2020, 31 Mart). Covid-19 and its impact on the Roma community: The case of Spain [Blog yazıs1]. Erişim adresi: http://somatosphere.net/forumpost/covid-19-roma-community-spain/

Gilmore, W. R. (2010). Fatal couplings of power and difference: notes on racism and geography. The Professional Geographer, 54(1), 15-24. doi:https://doi.org/10.1111/00330124.00310

Giritli İnceoğlu, Y. (2020, 23 Eylül). Covid-19'un dışladığı yoksul ve kırılgan grup: Romanlar. (2020). Bianet. Erişim adresi: https://m.bianet.org/

Golding, P. ve Murdock, G. (1997). Kültür, iletişim ve ekonomi politik. (D. Beybin Kejanlığlu, Çev.). S. İrvan (Ed.), Medya Kültür Siyaset (s.49-76) içinde. Ankara: Ark

Golechha, M. (2020). Covid-19 containment in Asia's largest urban slum Dharavi-Mumbai, India: Lessons for policymakers globally. J Urban Health, 97(6), 796-801. doi: 10.1007/s11524-020-00474-2.

Hancock, I. (2011, 10 Kasım). Romani origins and identity: New directions [Video]. Erişim adresi: https://www.youtube.com/watch?v=NTsqiP196Uw

Honey-Rosés, J., Anguelovski, I., Chireh, V. K., Daher, C., Konijnendijk van den Bosch, C., Litt, J. S., ... Nieuwenhuijsen, M. J.(2020). The impact of COVID-19 on public space: An early review of the emerging questions - design, perceptions and inequities. Cities $\mathcal{E}$ Health. doi:10.1080/23748834.2020.1780074

hooks, b. (1992). Black looks: Race and representation. Boston, MA: South End Press.

International Labour Organization. (2020). ILO Monitor: Covid-19 and the world of work (3. basım). Erişim adresi: https:/www.ilo.org/wcmsp5/groups/public/---dgreports/--dcomm/documents/briefingnote/wcms_743146.pdf

İstanbul'da Roman Havası. (2020, Ağustos). Haber Türk. Erişim adresi: https://www.haberturk.com/istanbulda-roman-havasi-2778519

Kağıt ve Hurda Toplayan Romanlar Virüsten Nasıl Korunacak. (2020, Mart). Evrensel. Erişim adresi: https://www.evrensel.net/haber/399681/kagit-ve-hurda-toplayan-romanlar-virusten-nasil-korunacak

Karadağ, A. (2020, 18 Haziran). Çeşme'de 300 Roman yurttaş evsiz kaldı. Birgün. Erişim adresi: https://www.birgun.net/

Kaya, İ. (2020, 8 Nisan). Roman yurttaşlar koronavirüs kaygısı içinde fark edilmiyoruz. Cumhuriyet. Erişim adresi: https://www.cumhuriyet.com.tr/

Kaytanbay, E. (2020, 7 Nisan). Roman vatandaşların bize yardım verilmedi isyanı. Sözcü. Erişim adresi: https://www.sozcu.com.tr/

Kılıç, T. (2020, 29 Nisan). Nazillili davulcular destek bekliyor. Ses Gazetesi. Erişim adresi: https://www.sesgazetesi.com.tr/ 
Kurban, D. ve Sözeri, C. (2012). İktidarın çarkında medya, demokratikleşme programı (Medya raporları serisi 3). İstanbul: TESEV Yayınları.

Landman, K. (2020). Inclusive public space: Rethinking practices of mitigation, adaptation and transformation. Urban Design International, 25(211), 211-214. doi: https://doi.org/10.1057/s41289-020-00136-4

Lewis, O. (1968). The culture of poverty. L. A. Ferman, J. L. Kornbluh ve A. Haber (Ed.), Poverty in America (s. 405-415) içinde. Ann Arbor: The University of Michigan Press.

Lewis, O. (1969). The Culture of Poverty. D.P. Moynihan (Ed.), On Understanding Poverty (s. 181-193) içinde. New York: Basic Books Inc. Pub.

Lüleburgaz'da 100 Davulcu Ramazanda Görev Yapacak. (2020, Nisan). Haberler.com. Erişim adresi: https://www.haberler.com/luleburgaz-da-100-davulcu-ramazanda-gorevyapacak-13136825-haberi/

Matache, M. ve Bhabha, J. (2020). Anti-roma racism is spiraling during Covid-19 pandemic. Health Hum Rights, 22(1), 379-382. Erişim adresi: https://www.hhrjournal.org/2020/04/anti-roma-racism-is-spiraling-during-covid-19-pandemic/

McLanahan, S. S. ve Kelly, E. L. (1999). The feminization of poverty: Past and future. J. S. Chafetz (Ed.), Handbook of the sociology of gender (s. 127-45.) içinde. New York: Kluwer Academic/Plenum.

Merrifield, A., Negri, A. Bayat, A., Harvey, D., Wacquant, L., Amoros, M. ve Torlak, S. (2014). Mekân meselesi. İstanbul: Tekin Yayınevi.

Mollaer, F. (2020, 18 Kasım). Kültür leviathanı: Sağ kültürelciliğin kaynaklarına giriş [Blog Yazısı]. Erişim adresi: https://terrabayt.com/dusunce/kultur-leviathani-sag-kulturelciligin-kaynaklarina-giris/\#_ftnref1.

Nida, H. (2020a, 12 Kasım). Kapı kapı dolaşarak Roman kadınlara İstanbul Sözleşmesi'ni anlatiyor. Gazete Duvar. Erişim adresi: https://www.gazeteduvar.com.tr/

Nida, H. (2020b, 23 Temmuz). Roman kadınlar, AB Türkiye Delegasyonu Başkanı ile bir araya geldi: Onurlu bir yaşam istiyoruz. T24. Erişim adresi: https://t24.com.tr/

Örnekköy'de Örnek Mesai. (2020, Mayıs). Milliyet. Erişim adresi: https://www.milliyet.com.tr/ege/ornekkoyde-ornek-mesai-6215852

Pearce, D. (1978). The Feminization of poverty: Woman work and welfare. Urban And Social Change Review, 11(1), 28-36.

Reuters Staff. (2020, 17 Nisan). Bulgaria's Roma fear Coronavirus lockdowns leave them with no means to live [Blog yazıs1]. Erişim adresi: https://www.reuters.com/article/us7health-coronavirus-bulgaria-roma/bulgarias-roma-fear-coronavirus-lockdowns-leavethem-with-no-means-to-live-idUSKBN21Z362

Roman İlahi Grubundan Korona Konseri. (2020, Nisan). Sabah. Erişim adresi: https://www.sabah.com.tr/canakkale/2020/04/25/roman-ilahi-grubundan-koronakonseri

Roman Kadınlar Anlatıyor: Duymadıklarımızı Belgeseli Yayınlandı. (2020, Kasım). Gazete Duvar. Erişim adresi: https://www.gazeteduvar.com.tr/roman-kadinlar-anlatiyorduymadiklarimizi-belgeseli-yayinlandi-haber-1504808 
Roman Mahallesinde Gün, Büyükşehir' in Sıcak Çorbasıyla Aydınlanıyor. (2020, Aralık). Tele1. Erişim adresi: https://tele1.com.tr/roman-mahallesinde-gun-buyuksehirin-sicakcorbasiyla-aydinlaniyor-292852/

Roman Milletvekili Purçu'dan Korona Uyarısı: "Romanlar Korona Salgınına Karşı Çaresiz". (2020, Mart). Gazetem İzmir. Erişim adresi: https://www.gazetemizmir.com/roman-milletvekili-purcu-dan-korona-uyarisi-romanlar-korona-salginina-karsi-caresiz/57398/

Roman Müzisyenler İşçiler İçin Çaldı. (2020, Nisan). Haberler.com. Erişim adresi: https:/www.haberler.com/roman-muzisyenler-isciler-icin-caldi-13177393-haberi/

Roman Müzisyenler İstanbullularla Buluşuyor. (2020, Ağustos). Cumhuriyet. Erişim adresi: https://www.cumhuriyet.com.tr/haber/roman-muzisyenler-istanbullularla-bulusuyor-1759803

Roman Partisi Resmen Kuruldu: Seçimlerde İddialılar. (2020, Ağustos). Yeniçă̆. Erişim adresi: https:/www.yenicaggazetesi.com.tr/roman-partisi-resmen-kuruldu-secimlerdeiddialilar-294635h.htm

Romanlar 49 Yıl Sonra İlk Defa Sessiz Kaldı Romanlar Korona Virüsü Nedeniyle Günlerini Kutlayamadı. (2020, Nisan). Haber Türk. Erişim adresi: https://www.haberturk.com/aydin-haberleri/77001001-romanlar-49-yil-sonra-ilk-defa-sessiz-kaldiromanlar-korona-virusu-nedeniyle-gunlerini

Salama, A. M. (2020). Coronavirus questions that will not go away: Interrogating urban and socio-spatial implications of COVID-19 measures [version 1; peer review: 3 approved]. Emerald Open Research, 2(14), 1-16. doi: https://doi.org/10.35241/emeraldopenres.13561.1

Sivrikaya, E. (2020, 20 Kasım). Roman kadınlar anlatıyor çözülmesi gereken çok problem var. Gazete Duvar. Erişim adresi: https:/www.gazeteduvar.com.tr/

STK'lardan Ortak Açılama: Roman Aileden Özür Dilensin. (2020, Nisan). Euronewss. Erişim adresi: https://tr.euronews.com/2020/04/09/stk-lardan-ortak-ac-klama-roman-aileden-ozur-dilensin

Tampe, T. (2020). Potential impacts of COVID-19 in urban slums: Addressing challenges to protect the world's most vulnerable. Cities \& Health, 389(10068), 1-4. doi: $10.1080 / 23748834.2020 .1791443$

Tok, H. (2020, 5 Nisan). Roman kadınların koronavirüs günleri çocuğuma yedirmek için ebegümeci topluyorum. Evrensel. Erişim adresi: https://www.evrensel.net/

Tokdoğan, N. (2013). Hak haberciliğinde temel bir uğrak: Kadın odaklı habercilik ve Jinha örneği. Mülkiye Dergisi, 37(3), 9-35. Erişim adresi: https://dergipark.org.tr/tr/download/article-file/159

Tokyay, M. (2020, 20 Temmuz). AB Türkiye'deki Roman kadınlara destek veriyor. Euronews. Erişim adresi: https://tr.euronews.com/

Torun, T. (2020, 28 Nisan). Roman halkının virüsle imtihanı. Gazete Duvar. Erişim adresi: https://www.gazeteduvar.com.tr/

Tunç Cox, A. ve Uştuk, O. (2019). The Roma image in the mainstream Turkish audiovisual media: Sixty years of stereotyping. Romani Studies, 29(2), 159-179. doi: 10.3828/rs.2019.7 
Ulaşamadığımız Kimse Kalmasın İstiyoruz. (2020, Ekim). Çağdaş Kocaeli. Erişim adresi: https://www.cagdaskocaeli.com.tr/foto/5619732/ulasamadigimiz-kimse-kalmasin-istiyoruz

UN-Habitat. (2011). State of the world's cities 2010/2011. London: Earthscan Publishing.

UN-Habitat. (2015). Slum almanac. Nairobi: UNON.

United Nations Development Programme. (2020). Coronavirus vs. inequality. Erişim adresi: https://feature.undp.org/coronavirus-vs-inequality/

Ürgir, B. (2020, 18 Haziran). Çeşme'de Roman vatandaşların yaşadığı çadırların yıkılması sosyal medyanin gündeminde. Listelist. Erişim adresi: https://listelist.com/

Uş̧tuk, O. (2021). Roman kimliğinin çatışmalı inşası: "Fotokopi Romanlık" karşısında otantik Romanlık. Folklor Edebiyat. 27(1), 151-166. doi: 10.22559/folklor.1271

Van Criekingen, M. ve Decroly, J. M. (2003). Revisiting the diversity of gentrification: Neighbourhood renewal processes in Brussels and Montreal. Urban Studies, 40(12), 24512468. doi: $10.1080 / 0042098032000136156$

Van Dijk, T. A. (2005). Söylemin yapıları ve iktidarın yapıları. M. Küçük(Ed.), Medya, iktidar, ideoloji (s. 315-376) içinde. Ankara: Bilim ve Sanat Yayınları.

Wiemers, E. E., Abrahams, S., Alfakhri, M., Hotz, V. J., Schoeni, R. F. ve Seltzer, J. A. (2020). Disparities in vulnerability to severe complications from Covid-19 in the United States. medRvix, 1-37. doi: 10.1101/2020.05.28.20115899

Yıldızalp Özmen, M. (2020, 9 Nisan). CHP Romanlara ilişkin politika notu hazırladı. Anadolu Ajansı. Erişim adresi: https://www.aa.com.tr/

Yilmaz, G. (2020, 24 Nisan). İstanbul'da ramazan davulcuları maske takarak mesaiye başladı. Anadolu Ajansı. Erişim adresi: https://www.aa.com.tr/

Yılmaz, Ş. (2020, 16 Aralık). Roman vatandaşların hizmete erişimi ile ilgili eylem planı değerlendirildi. Sabah. Erişim adresi: https://www.sabah.com.tr/ 